\title{
Expanding Learning Frames in Music Teacher Education: Student Placement in a Palestinian Refugee Camp in Lebanon

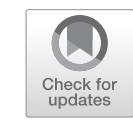

\author{
Brit Ågot Brøske
}

\begin{abstract}
The purpose of this chapter is to discuss how intercultural music projects can contribute to expansive learning in music teacher education. Based on culturalhistorical activity theory (CHAT), I explore expansive learning on the studentmusic-teacher and institutional levels. The inspirational starting point for the chapter is the professional placement of student music teachers in the Palestinian refugee camp Rashedieh in South Lebanon. Both students and staff from the Norwegian Academy of Music are involved in this project, and both the context and the content of the setting are experienced by student-music-teachers and staff as highly unfamiliar, unpredictable, and challenging-although highly valuable. A particular focus of the discussion relates to the concepts of complexity and contradictions, and how they can function as potential sources for change, development, and expansive learning. I argue that student-music-teachers' involvement in intercultural projects can create rich opportunities for expansive, intercultural learning. However, in order to achieve this, we have to design educational programs that enhance reflection and dialogue, provide a solid intercultural competence, and create possibilities for existential meetings and placement settings in which student-teachers experience being "the other". Consequently, students, teachers, and institutions can learn something that is "not yet there", and be prepared for the crucial challenges of the future.
\end{abstract}

Keywords Music teacher education - Intercultural projects · Professional placement $\cdot$ Expansive learning $\cdot$ Palestinian refugees

\footnotetext{
B. Å. Brøske $(\bowtie)$

Music Education and Music Therapy Department, Norwegian Academy of Music,

Oslo, Norway

e-mail: brit.a.broske@nmh.no
}

H. Westerlund et al. (eds.), Visions for Intercultural Music Teacher Education, Landscapes: the Arts, Aesthetics, and Education 26,

https://doi.org/10.1007/978-3-030-21029-8_6 


\section{Introduction}

This chapter explores learning by taking student music teachers to an intercultural project held in a Palestinian refugee camp in South Lebanon. The Norwegian Academy of Music (NMH) has been involved in a project in Lebanon (known as the "Lebanon Project") $)^{1}$ since 2005 (for more information, see Storsve and Danielsen 2013). This project can in different ways be seen as an important learning arena for both the student music teachers participating in the professional placement training and for $\mathrm{NMH}$ as an institution.

In this chapter, cultural-historical activity theory (CHAT) is used as a way of understanding learning opportunities within the music project in the refugee camp. Activity theory is particularly useful when exploring and understanding learning that involves the interaction of at least two activity systems (Engeström 1987; Engeström and Sannino 2010; Vennebo 2016). This is one way of considering the interaction between NMH and the professional placement arena in Lebanon. In particular, the present study will focus on complexity and contradictions as potential sources for change, development, and expansive learning. When encountering an unfamiliar context characterized by a high degree of complexity and unforeseen challenges, questioning and reflecting on one's own competence seem to be central catalysts for learning in projects where different cultures meet; I label this 'intercultural projects' in this chapter. I posit that intercultural projects can create opportunities to expand on the aim of the activity, which in this context is both to teach children music as well as to better understand music teaching within higher music teacher education. The following research question is posed: What kind of expansive learning takes place in an intercultural professional placement in music education at the individual and institutional levels? How can such learning inform music teacher education?

This chapter is divided into three sections. In the first part of the chapter, I present the context: the Lebanon Project, theoretical perspectives, and previous relevant research. Then, I turn to discussions and reflections on expansive learning at the student-music-teacher level. This is based on my own previous research on students' learning experiences after partaking in a professional placement in Rashedieh (Brøske-Danielsen 2013). Activity theory is especially valuable for focusing not only on learning at the individual level, but also at the institutional, or system, level. In the third part of the chapter, I discuss how such a project can contribute to expansive learning at the institutional level, and in what ways such learning can inform music teacher education.

\footnotetext{
${ }^{1}$ https://nmh.no/forskning/prosjekter/libanonprosjektet
} 


\section{The Lebanon Project: Context and Content}

In 2002, Norwegian music teachers introduced community music activities for children in the Palestinian refugee camp Rashedieh in South Lebanon. This has grown into a large project called the Lebanon Project, and the Norwegian Academy of Music (NMH) has been a central partner in it since 2005. The refugees in Rashedieh lack basic human rights and access to education; moreover, the unemployment rate is high, the economy is poor, and the camp lacks clean water and adequate health care. Further, there are few or no opportunities for children and adolescents to continue their music education outside of the camp, due to their refugee status. The music activities in Rashedieh take place in a cultural center run by a nongovernmental organization: Beit Atfal Assumoud. Local instructors run the music activities and teach music as a permanent, weekly activity. A large orchestra with a mixture of instruments forms the core of the project, in which children and adolescents from 7 to 20 years old play together, all with different skills and musical backgrounds. In addition to the music activities offered in the refugee camp, the Lebanon Project establishes music as part of the curriculum in Lebanese schools, and trains Lebanese and Palestinian music teachers in Lebanon-all led by music teachers from NMH.

The student music teachers' professional placement occurs mainly within a Muslim cultural context in which music is neither common as a leisure activity nor as a school subject. Music is considered by some Muslims as haram (forbidden), while others deem it a valuable and desirable activity (Harris 2006; Izsak 2013). Through community music activities, the project in Rashedieh aims to promote equal rights and contribute to cultural democracy (Brøske-Danielsen 2016; Brøske 2017). Such ideologies can occasionally be seen as being in opposition to the social and religious hierarchical structures in the camp (Brøske-Danielsen 2016), and the project is itself replete with internal ideological contradictions (Brøske 2017). Relevant issues arise about gender (views on what girls could or could not do), on what kinds of music are acknowledged, and to what extent and how children with special needs could be included in the musical practices. These are issues that undergraduate student music teachers at $\mathrm{NMH}$ encounter during their professional placement in Rashedieh. The professional placement aims to broaden the students' understanding of their role as music teachers and to prepare them for a varied professional career. When placed in the refugee camp, student teachers administer and teach music activities for children and give concerts in the camp and in Lebanese schools. By doing so, the students are given the opportunity to encounter unfamiliar people, music, traditions, and cultures, as well as to gain knowledge that extends the context- and discipline-specific aspects of music teaching and learning.

Although currently limited to a group of Norwegian researchers and teachers, the Lebanon Project offers much greater potential for participation. Future areas for research and developmental work encompass the fields of music education, music therapy, and community music. Thus far, project-related publications have focused on the value of music activities for participating Palestinian children in terms of 
offering them new roles and possibilities to experience mastery, meaning, and improved quality of life (Ruud 2011; Storsve et al. 2012). Research studies have found that interaction between Palestinian and Lebanese children and Norwegian teachers facilitates new ways of understanding the self, experiencing recognition, and gaining respect and equality for the Palestinian refugee children (Boeskov 2013).

Other studies have focused on the need for competence development among music teachers working in Rashedieh refugee camp (Ruud 2012), and student music teachers learning in refugee camps or similar settings (Brøske-Danielsen 2013). When leading and carrying out music activities in a different and unfamiliar culture, several dilemmas and contradictory values and goals seem to arise. Recently, I have critically discussed these phenomena, theorizing how aiming to create a culture of equality and cultural democracy can conflict with the ideology and social structures of the local culture (Brøske 2017). My finding demonstrates the importance of focusing on learning and building formalized organizational structures within this specific community music project.

\section{Sociocultural Activity Theory}

Activity theory (CHAT) is based on the notion that learning and development takes place in and through social participation (Engeström 1987). It has its roots in the works of Vygotsky and the notion of mediating artifacts (Vygotsky 1978). CHAT has developed over several generations. Leont'ev (1981) developed the understanding that individual and group actions are embedded in a collective activity system. Activity systems can be defined as a group of people sharing a joint objective or motive (de Lange 2014); they are multi-voiced, object-oriented, and negotiated and constructed by participants (Engeström 2001). Six components—subject, object (referring to what the activity is directed towards), mediating artifacts, community, rules and division of labor - together constitute an activity system in which the components are interconnected and interdependent (Engeström 1987, 1999, 2001; de Lange 2014).

The third generation of CHAT includes at least two interacting activity systems (de Lange 2014). These activity systems consist of different perspectives, understandings, traditions, and interests at the same time. Such multiplicity is included in the term multivoicedness and is related to the notion of contradictions as driving forces and the basis for development and change (Engeström 2001). Multivoicedness and contradictions constitute two of total five central principles in activity theory. Taking an activity system as the prime unit of analysis is another central principle, and the fourth principle is that activity systems transform over periods of time and have to be understood against their historical development (Engeström 2001). Negotiating institutional boundary areas contributes to creating contradictions, which enable expansive learning cycles. Expansive learning cycles entail that the learner constructs new objects and concepts for the collective activity (Engeström 
1999; Engeström and Sannino 2010); learning "new forms of activity which are not yet there" (Engeström 2001, p. 138). Expansive learning cycles start with questioning existing practice (Engeström 1999), and are followed by analyzing and modeling new solutions and consolidating the new practice (Engeström 1999; Vennebo 2016). The possibility of expansive transformations is the fifth principle of activity theory (Engeström 2001). Expansive transformations are discontinuous by nature, as the learning process is often full of leaps, disruptions, misunderstandings, and conflicts, yet: "discontinuities between communities, although potentially troublesome, also represent opportunities for learning" (Hubbard et al. 2006, p. 17). Such discontinuous and expansive learning processes can take place throughout the activity system, in the objective of the activity, or in the people involved. There are some similarities between this complex idea of learning processes and Bollnow's (1976) understanding of the term existential meeting, entailing a decisive, existential, and paramount experience which forces the individual to reorient as their very existence is affected. In particular, there are similarities in focusing on learning as discontinuous and dependent on questioning one's own understanding and actions, on the one hand, and, in Bollnow's understanding, learning that demands personal involvement (Bollnow 1976), on the other.

This chapter considers the interaction of two activity systems: (1) NMH; and (2) Rashedieh camp and its music activities. In several obvious ways, these two systems are very different; however, that is not the primary focus here. Instead, the focus is on how multivoicedness and contradictions are driving forces for expansive learning both at a student and an institutional level when operating in a boundary practice (Star and Griesemer 1989). A boundary practice is a practice in which two communities engage; it becomes "established and provides an ongoing forum for mutual engagement" (Wenger 1998, p. 114). In addition to briefly touching upon the six components of the activity systems: subject matter, objective, mediating artifacts, rules and division of labor, I deal with expansion of the object, understood as the outcome of the activity in great detail. Perspectives from and research on CHAT (Engeström 1987) and boundary practices (Akkerman and Bakker 2011; Star and Griesemer 1989) provide a theoretical framework for examining and understanding common challenges faced by partnerships (Waitoller and Kozleski 2013).

\section{Expansive Learning: The Student Perspective}

I will now turn to perspectives on the involvement of student music teachers in the Lebanon program. I base my examination on previous research about what student music teachers have learned from participating in the Lebanon program. In this previous research, the students' data was collected through reflective journals where the student teachers reflected on their experiences of participating in the professional training at Rashedieh camp (Brøske-Danielsen 2013). The study showed that the student teachers' experience in the Palestinian refugee camp could be characterized by encountering the unfamiliar and unexpected, which forced the students to 
confront new dilemmas and issues to which they had to adjust and handle, and on which they were required to reflect. The setting presents both cultural and pedagogical unfamiliarities and differences that contribute to increased reflection and questioning (Brøske-Danielsen 2013). In the following, I will focus on these two areas of interest - cultural differences and pedagogical complexity - incorporating perspectives from activity theory as a central part of the discussion. In the concept of CHAT, cultural differences and pedagogical complexity can be seen as multivoicedness and as central issues leading to contradictions (Engeström 2001). What students learn from the Lebanon program, how the learning takes place, and what conditions lead to this learning will be addressed in the following. But first, I will describe a typical day for the Norwegian students in Rashedieh camp.

\subsection{A Typical Working Day in Rashedieh Camp}

In Rashedieh camp, around 50 children welcome the Norwegian students through a small concert featuring both Arabic and western music. Then the students teach and lead for the rest of the day, starting with some musical games and warm-up activities, before moving on to prepared musical material: a multi-use arrangement ${ }^{2}$ based on a song or tune. A multi-use arrangement entails having ideas and sketches of different voices and possibilities for different instruments, and several issues still to be decided, depending on the students' ability to make professional decisions on the spot. There are several challenges encountered throughout the day, such as working with translators as several of the children do not speak English very well. There is a lack of rooms suitable for practicing in smaller instrumental groups, and studentteachers and children face communication challenges, creating the need for regular breaks to translate instructions. There are several breaks and interruptions made throughout the session as the electricity comes and goes, leading to no sound on the keyboards, electric guitars, or the bass, and when the boys attend Friday prayers. After the workshop in Rashedieh, the teachers from NMH lead afternoon reflective sessions for the student-teachers that focus on sharing and making sense of their experiences; adjusting to various classroom material and teaching strategies; organizing for the next day; and exchanging feedback among students and between students and teachers.

\subsection{Cultural Differences}

As exemplified in the description of an average working day, the professional placement in Rashedieh camp is rife with unfamiliar and unpredictable experiences for the students. The context is characterized by the lack of a common language between

\footnotetext{
${ }^{2}$ For more information on this, see Brøske-Danielsen and Storsve (2016).
} 
student-teachers and children, the lack of a mutual understanding regarding gender and religious issues, and the reality that the children are refugees with little hope and few prospects for the future. The student-teachers are moving from one activity system, represented by NMH and music education in Norway, to another activity system represented by Rashedieh camp and the music activities there. They experience the context in Rashedieh camp featuring both intrinsic multivoicedness and contradictions, as well as contradictions between the unfamiliar Rashedieh system and their familiar situation in Norway. Contradictions are found on several levels, which is a central feature in activity theory and a driving force for expansive learning (de Lange 2014). Based on this understanding, the context can be considered well suited to enabling expansive learning. Within expansive learning cycles, contradictions lead to questioning, and "the object and motive of the activity are reconceptualized to embrace a radically wider horizon of possibilities than in the previous mode of the activity" (Engeström 2001, p. 137). The contradictions and unfamiliarities can then be seen as key conditions for the reconceptualization of the objective of the activity and for the learning that takes place.

A previous study (Brøske-Danielsen 2013; Danielsen 2012) shows that teaching in collaboration with fellow student-teachers in this challenging context contributes to increased awareness of competence, as students experience and acknowledge both themselves and the other students as competent music teachers (BrøskeDanielsen 2013). When the student-teachers have to implement all their previous achieved competence, they realize how their competences are useful and valuable in other contexts than where the competence was first gained. For student-teachers, participating in the program positively impacts their self-confidence as developing professionals and in their personal lives (Brøske-Danielsen 2013). Furthermore, the study shows that when the student-teachers encounter refugee children who are part of a vulnerable group, it contributes to the student-teachers' reflections on the value of music, giving them a renewed understanding of their own role. As a result, student-teachers shift their focus from their own personal, artistic achievements to consider the refugee children's needs in the teaching situation (Danielsen 2012). This shift leads to a reconceptualization of the students' prior understanding, biases, choices, and actions (Danielsen 2012). Building on perspectives of expansive learning, this reconceptualization can be understood as the students expanding their understanding of the object of music education.

\subsection{Pedagogical Complexity}

The context in Rashedieh camp is characterized by a high degree of pedagogical complexity, underlining the multivoicedness (Engeström 2001) of this activity system. There are extremely large variations in age and skill among the participating children. We do not know in advance how many children will attend or how many interruptions there will be, for example, owing to electricity outages or absences when all the boys leave to attend Friday prayers. Throughout the workshops, it is 
unfamiliar and challenging for the student-teachers to collaborate and teach together in a large group, and to work with a translator. These challenges place special demands on the teachers' choice of musical material, teaching strategies, and organization of activities (Brøske-Danielsen and Storsve 2016). This demanding situation for the teacher is similar to experiences in a collaboration between Finland and Cambodia (Westerlund et al. 2015). In both situations, student-teachers were required to step out of their comfort zones and engage in deep reflections on the nature of teaching and the purpose of music education. Both these studies show that language barriers contributed to a more nuanced understanding of the use and value of verbal instructions, while favoring the use of body language and instrumentdemonstrations as the primary means of communication and teaching (BrøskeDanielsen 2013; Westerlund et al. 2015).

The context in Rashedieh constitutes an unpredictable, complex, and challenging teaching situation (Brøske-Danielsen 2013). This finding contradicts the proposal that professional placements should be of reduced complexity, where studentteachers can practice on specific components of their vocational tasks within a manageable context (Grossman et al. 2009). In Rashedieh camp, the student-teachers encounter a context that demonstrates a higher degree of complexity than normal, and-as something else appears to be more important, such as playing music with refugee children - the student-teachers seem to handle the complex situation together. The student-teachers are forced to gain experience in facing the unknown, while seeing themselves and their fellow students as competent music teachers. At the same time, the student-teachers collaborate with each other, which seems to make it possible for them to handle challenging situations. It seems that being able to handle and act on the unknown and unfamiliar constitutes an important part of their intercultural competence by being able to adjust to different cultures and settings and make sense of different ways of approaching music and music education.

\subsection{The Need for Reflection}

A central element of professional placement is the emphasis on reflection, carried out through reflective dialogues to which both teachers from the Academy and peer students contribute. As mentioned above, encountering this complex and rather different culture and context forces the student-teachers to step out of their comfort zones, which, in part, forces them to question their teaching strategies and conceptions of the value of music (Brøske-Danielsen 2013). In CHAT, questioning is considered the first step in the expansive learning cycle (Engeström and Sannino 2010; Rantavuori et al. 2016). Reflection is then crucial for making sense of the students' daily experiences. Reflection was also found to be crucial for Master's students studying performance who participated in a complex and challenging professional placement, according to the research study of Brøske and Sætre (2017). Their study 
shows that as students experience and encounter things that they find challenging, reflective everyday conversations become a necessity. When encountering a variety of unfamiliar elements, reflective conversations become a valuable and familiar part of the students' day (Brøske and Sætre 2017). Although this has not been studied within the Lebanon program, it is reasonable to hypothesize that similarities could be confirmed, as the student-teachers in the Lebanon program also experienced the setting as challenging and unfamiliar. It seems that this comparison confirms the importance of reflective conversations between students within placements that are complex, challenging, and unfamiliar.

\subsection{Questioning as a Starting Point}

An important aspect of the reflective dialogues is their questioning of the accepted practice and existing wisdom; and this questioning constitutes the first step in an expansive learning cycle (Engeström 1999). Joint reflections can be seen as conditions for the learning that takes place in the Lebanon program. Encountering, or meeting, the unfamiliar teaching context forces the student-teachers to draw on all their previously gained competence (Brøske-Danielsen 2013). Subsequently, as the unknown becomes familiar, they can consider what they know and reflect on this knowledge in new ways and through new lenses. By identifying, reflecting on, and assessing unspoken conditions, student-teachers gain new understanding. Personal involvement is then crucial for this development. The feeling of doing something that matters to others is important for the student teachers, and makes it impossible for them to continue unaffected (Brøske-Danielsen 2013).

This feeling is in line with Bollnow's (1976) understanding of an existential meeting, as well as Engeström's (2001) understanding of the role of contradictions as a driving force for questioning within the theory of expansive learning. When meeting something unusual and paramount, in which the individual is fully engaged and involved, the learner must reorient her view and start questioning her own preconceptions and prior understanding. The students' questions and reflections not only concern the actual teaching in the refugee camp, but may even extend to their overall ideas on the value of music and teaching, teaching strategies, understandings of culture, and their role as music teachers (Brøske-Danielsen 2013). Such questioning can contribute to new approaches and understandings when teachers meet other target groups, both in familiar and unfamiliar teaching contexts. This questioning can be further expanded to a way of operating and thinking, or, in other words, to new habits of mind and action, and to expanding learning cycles (Engeström 2001). This is one of the most valuable outcomes and one of the most important reasons for carrying out this program. The student teachers encounter people from another culture through and in music, thereby experiencing being "the other", and hence being forced to question things hitherto taken for granted. Creating 
the conditions for this to happen would be a good starting point for intercultural music education. Based on the established value of the process and outcome, the professional placement can be considered highly relevant for the student teachers' future work, although it is not authentic or similar to contexts that the student-teachers will probably encounter later in life. The students gain experience in learning "what is yet not there" (Engeström 2001, p. 138), as they cannot anticipate the competences and skills they will need to employ in such an unimagined teaching context.

\subsection{The Value of Encountering the Unforeseen}

As shown thus far, there are several reasons for bringing student music teachers to professional placement settings like the Lebanon program, including to increase student-teachers' intercultural competence. I would, however, underline that the significance of such programs is not primarily about learning specific cultural content, such as learning Arabic music; rather, it is about encountering a demanding and contradictory situation in which meeting a marginalized group of people offers new understandings, and leads to a questioning and enrichment of the object of the activity. Student-teachers gain new understandings of themselves as people and as professionals, and have the opportunity to unconditionally welcome everyone in a musical community.

\section{Expansive Learning: The Institutional Perspective}

The theory of expansive learning focuses on learning processes in which subjects of learning are transformed from isolated individuals into collectives and networks, and the focus is on "communities as learners" (Engeström and Sannino 2010). Nevertheless, the complex interrelations between the individual subject and her community is at the core of CHAT and the theory of expansive learning (Engeström 2001). In expansive transformations and in interactions between two or more activity systems, the object of the activity can be reconceptualized to embrace a radically wider horizon of possibilities than in the previous mode of the activity (Engeström 2001). The collaboration or interaction between NMH and Rashedieh can be understood as the overlap of two activity systems. This overlap occurs in a boundary practice as these two communities are mutually engaged (Waitoller and Kozleski 2013). In themselves, as well as between one another, the two systems are both filled with multiple voices and contradictions (Brøske 2017) that can be a driving force for change and expansive learning, and can lead to a reconceptualization of the object of the activity (Engeström 2001). In the following, I will focus on expansive learning at an institutional level, and specifically on possibilities for and barriers to expansive learning in a higher music education institution like NMH when 
interacting with a community music project, such as the one in the Rashedieh refugee camp.

\subsection{Expansive Learning Among Higher Education Staff}

The fact that higher education staff from NMH participate differently in the professional placement and in the Lebanon Project as a whole can, on a system level, contribute to developing a common and joint understanding of perspectives and needs in an intercultural field, and expansion in music teacher education. This new understanding and expansion relates not only to how to operate within an international project, but also to how we can bring perspectives and experiences from the project into the ongoing work at $\mathrm{NMH}$, wherever they are relevant. In the same way that student-teachers are forced to reconstruct and adjust their understandings, values, and objects for the activity, higher education staff and researchers must adapt when participating in intercultural projects. Such participation can contribute to gaining valuable experience in communicating and operating within an unfamiliar context, facilitating music education in a Muslim culture, and understanding cultural and religious issues and contradictory dilemmas. Understanding cultural issues and contradictory dilemmas can lead to an enrichment of the repertoire of being a music teacher, or expansion of the object of the activity in terms of activity theory (Engeström and Sannino 2010).

As society changes, so too must music teachers and musicians in order to consider how to include refugees and immigrants in music activities in society, and how to engage all members of society in music education. Music teacher education needs to cover a broad range of issues relating to democracy and equity, and be able to engage with current matters in society. To initiate such changes, enhancing expansive learning could be the starting point for music teacher education, starting with questioning accepted practice and moving on to modeling new practices (Engeström 2008). This process could lead to expansion of the object, not only as it relates to cultural and religious issues, but as it challenges the understanding of basic issues in music teaching that are often taken for granted. These could be issues such as the concepts of talent, progression, and practice as cornerstones when learning music.

\subsection{Educating Music Teachers to Meet Societal Needs}

Municipal Music and Art Schools in Norway constitute an important professional field for educating music teachers. If the music teacher education at $\mathrm{NMH}$ and similar institutions are to be relevant to the field of teacher education, meeting the needs of these schools is important in terms of what kinds of competence music teachers need. There is now a call from national authorities to the Norwegian Municipal Music and Arts Schools to take greater part in cultural activities in reception centers 
for asylum seekers and in activities to promote the inclusion of immigrants granted residence (Brøske and Rønningen 2017). ${ }^{3}$ There is also a shift in focus for the Municipal Music and Arts Schools through a new curriculum plan, emphasizing a broad ranging program, including scope for artistic activities organized in large groups that do not require pupils to have certain skills or put in extra effort (Kulturskolerådet 2017). ${ }^{4}$ Incorporating intercultural projects into music teacher education, such as the Lebanon program, can contribute to building competence among music teachers in how to adjust musical material to a varied and complex ensemble, and how to develop teaching strategies suitable for both working with refugees or immigrants as well as more generally working with varied and large groups of children.

Furthermore, encountering Muslim culture can contribute to creating new understandings of refugees from Muslim countries, and challenge biases on this issue. Finally, experiences gained from participating in such intercultural projects could lead to a more nuanced and renewed understanding of the joy of music and the value of the community of practice within music activities. When meeting refugees in Rashedieh, contradictions between the expectations of high quality, development, and progress in Norwegian children's musical learning and among refugees in Lebanon is brought to the fore (Brøske and Rønningen 2017). It seems that participating in intercultural projects can contribute to challenging the notion of quality and musical progress as conditions for quality and learning in music teaching. Debates on progress, development, and quality are ongoing in the whole field of music teaching in Norway, where a common understanding seems to be that the goal of instrumental instruction is always to become the best possible performer. First-hand experiences from music activities in Rashedieh can enrich and nuance music teacher educators' understanding of progression and development as basic notions of quality and purpose in music teaching, and be a catalyst for expansive learning.

\subsection{Obstacles and Challenges}

Enabling expansive learning among $\mathrm{NMH}$ staff, and at $\mathrm{NMH}$ as an institution, requires that staff participate in international projects in several areas and ways, engage in intercultural music education practices and discussions in Norway, and are motivated to start to question their own understandings. This is not at the moment a realistic scenario, mostly due to few staff members participating in the project for

\footnotetext{
${ }^{3}$ A small-scale study was carried out among four music teachers working in Municipal Music and Art Schools in Norway, participating in the music activities in Rashedieh in August 2016 (Brøske and Rønningen 2017).

${ }^{4}$ http://kulturskoleradet.no/_extension/media/4683/orig/Strategidokument\%20Fokusomrade\%20 flyktninger\%20og\%20kulturskole\%205.1\%20per\%20170512.pdf
} 
several different reasons. One research study has underlined the importance of being willing to question prior understandings and assumptions. This study focused particularly on identifying barriers to collaboration within a partnership between primary schools and higher education (Waitoller and Kozleski 2013). Results from this study suggest that boundary practices where artifacts are questioned and expanded in a collective and democratic manner offer rich opportunities for development (Waitoller and Kozleski 2013).

Operating in a new and unfamiliar activity system as the "unknown" can contribute to creating disturbances and interruptions to the norm, thereby constituting the starting point for expansive learning. Boundary crossing entails contradictions and facing multivoicedness, and collaboration and dialogue are important for doing terms and understandings explicit and available for everyone involved (Waitoller and Kozleski 2013; Brøske 2017). Subjects may act as boundary-crossing change agents, carrying, translating, and helping to implement new ideas between the activity systems involved (Engeström and Sannino 2010). When participants shift their roles and tools and reconstruct the object of the activity, it can lead to changes in the activity systems (Waitoller and Kozleski 2013). Such changes demand that the subjects involved are willing and flexible enough to start questioning the established practice, and really interested in learning from the collaboration. Reticence to become personally involved and an unwillingness to challenge one's own understandings and practices is often easier, meaning that allowing intercultural projects to simply become exotic and interesting novelties is a real risk. Such simplification could lead to cultural fascination, or "cultural peeking", rather than expansive learning. Enabling expansive learning in intercultural projects on an institutional level is therefore dependent on the subjects' willingness to step out of their comfort zones and make a brave jump into the unknown (Sæther 2013).

\section{Towards Expansive Music Teacher Education}

If being able to encounter new and unfamiliar situations and people from a variety of cultures and traditions is a central part of intercultural competence in music teacher education, it is essential to move beyond a fascination with the exotic and the different. Focusing on embracing difference and contradictions, questioning one's own preconceptions, and reconstructing the competences and skills needed when meeting people from across different cultures, ethnicities, and religions could be a starting point. Such a starting point creates possibilities to move beyond "cultural peeking" (Knudsen 2010) when approaching the intercultural field. Doing so involves shifting the focus away from what is different, and embracing contradictions as a starting point for learning and development in terms of people, contexts, and cultures in all situations. Then, multiculturalism extends beyond ethnic labeling. Experiencing being "the other" through encountering a new and unfamiliar 
culture via the Lebanon program can be a push in this direction. The resulting hope is that an intercultural attitude can pervade everything we do, becoming a part of our everyday life, our behavior, and our work. When facing new or unfamiliar expressions and culture, it is then central to explore what is similar rather than what is (at first glance) different (Knudsen 2010). To have intercultural competence could then be about having a basic attitude that emphasizes respect and curiosity for all people rather than focusing on the exotic and different representations of cultural expression.

Several of the aspects discussed in this chapter concern the known and the unknown, the familiar and unfamiliar, and similarity and difference. Seeing the Lebanon program from the perspective of expansive learning provides additional ways of understanding how such intercultural projects have the potential to enhance and enable expansive learning. Both on-campus and regular placement settings are familiar to the students and hence characterized by routines and taken-for-granted elements. When placing student music teachers in professional placement settings, like primary and secondary schools or in Municipal Music and Art Schools, they enter an arena in which they have several years of experience and possess a lot of knowledge. Although this is a necessary placement for educating music teachers, I think that in order to meet future demands, especially related to intercultural challenges, it is necessary to bring student teachers to placement settings that are fundamentally intercultural. Such settings could, to a greater extent, stimulate new questions about teaching and learning practices, about elements taken for granted throughout their own upbringing and education, and contribute to creating a habit of questioning one's own practices, biases, and understandings. Then, I hope, that when returning to their own activity systems, or at least to known activity systems, they will have changed and will see music education, people, and challenges differently. This is expansive learning. Since contradictions are the driving forces of expansive learning, especially when dealt with through analyzing, testing out new models, and reflecting (Engeström 1999), intercultural projects can indeed function as particularly useful tools to enhance expansive learning.

The endeavor to educate music teachers for the future requires what I am tempted to call expansive music teacher education. The discussion and ideas presented in this chapter outline a vision for such music teacher education, and some of it can be summarized as follows:

- Creating conditions for expansive, intercultural learning by bringing student music teachers to intercultural projects where they experience being the "other" and meeting the unfamiliar;

- Meeting marginalized groups, such as refugees, during the educational program to contribute to new and nuanced understandings of concepts as quality, talent, and progress;

- Creating learning environments in which stepping out of comfort zones (high risk) is considered a low-risk endeavor; 
- Establishing rich arenas for reflection in order to make sense of the unfamiliar, and for analyzing and creating new models and understandings;

- Creating collaborative intercultural networks among higher education staff; and

- Creating a learning environment among higher education staff to enable questioning, analysis, and reconceptualization.

We have to design educational programs that potentially foster expansive learning, enhance reflection and dialogue, provide a solid intercultural competence, create possibilities for existential meetings, and create placement settings in which student-teachers experience being "the other". Hopefully, an expansive music teacher education may give students, teachers, and institutions access to experiences and possibilities to learn something that is not yet there and to be prepared for the crucial challenges of the future.

\section{References}

Akkerman, S. F., \& Bakker, A. (2011). Boundary crossing and boundary objects. Review of Educational Research, 81(2), 132-169. https://doi.org/10.3102/0034654311404435.

Boeskov, K. (2013). Meningsfyldte møder - om norsk-palæstinensisk kulturudveksling. In V. R. Storsve \& B. A. B. Danielsen (Eds.), Løft blikket - gjør en forskjell: erfaringer og ringvirkninger fra et musikkprosjekt i Libanon (pp. 127-148). Oslo: Norges musikkhøgskole.

Bollnow, O. F. (1976). Eksistensfilosofi og pedagogikk. Copenhagen: Christian Ejlers.

Brøske, B. A. (2017). The Norwegian Academy of Music and the Lebanon Project: The challenges of establishing a community music project when working with Palestinian refugees in SouthLebanon. International Journal of Community Music, 10(1), 71-84.

Brøske, B. A., \& Rønningen, A. (2017, March). Encountering the unfamiliar - Building intercultural competence. Experiences from a pilot project bringing music teachers to a Palestinian refugee camp in South-Lebanon. Paper presented at the Cultural Diversity in Music Education International Conference (CDIME XIII), Nepal.

Brøske, B. Å., \& Sætre, J. H. (2017). Becoming a musician in practice: A case study of professional work placement as part of specialist higher music education programmes. Music + Practice, 3(1) [Online]. http://www.musicandpractice.org/volume-3/becoming-musician-practice-casestudy/. Accessed 16 Feb 2018.

Brøske-Danielsen, B. Å. (2013). Community music activity in a refugee camp - Student music teachers' practicum experiences. Music Education Research, 15(3), 304-316.

Brøske-Danielsen, B. Å. (2016). Norges musikkhøgskole og Libanonprosjektet. Refleksjoner omkring et community music-prosjekt med palestinske flyktningbarn i Sør-Libanon. Paper presented at The 20th Conference of Nordic Network for Research in Music Education. Hamar, Norway, March, 2016.

Brøske-Danielsen, B. Å., \& Storsve, V. R. (2016). Musikkarbeid med palestinske flyktningbarn i Libanon. Et community music perspektiv. In K. Stensæth, V. Krüger, \& V. Fuglestad (Eds.), I transitt-mellom til og fra. Om musikk og deltagelse i barnevern (pp. 173-190). Oslo: Norges musikkhøgskole.

Danielsen, B. Å. B. (2012). Praksisbegrepet i musikklærerutdanning. In B. Å. B. Danielsen \& G. Johansen (Eds.), Educating music teachers in the new millennium (pp. 89-108). Oslo: Norges musikkhøgskole.

de Lange, T. (2014). Aktivitetsteori og læring. In L. Wittek \& J. H. Stray (Eds.), Pedagogikk - en grunnbok (pp. 162-177). Oslo: Cappelen Damm Akademisk. 
Engeström, Y. (1987). Learning by expanding: An activity-theoretical approach to developmental research. Helsinki: Orienta-Konsultit.

Engeström, Y. (1999). Innovative learning in work teams: Analyzing cycles of knowledge creation in practice. In Y. Engeström, R. Miettinen, \& R.-L. Punamäki-Gitai (Eds.), Perspectives on activity theory (pp. 377-404). Cambridge, UK: Cambridge University Press.

Engeström, Y. (2001). Expansive learning at work: Toward an activity theoretical reconceptualization. Journal of Education and Work, 14(1), 133-156.

Engeström, Y. (2008). From teams to knots: Activity theoretical studies of collaboration and learning at work. Cambridge: Cambridge University Press.

Engeström, Y., \& Sannino, A. (2010). Studies of expansive learning: Foundations, findings and future challenges. Educational Research Review, 5(1), 1-24.

Grossman, P., Hammerness, K., \& McDonald, M. (2009). Redefining teaching, re-imagining teacher education. Teachers and Teaching, 15(2), 273-289.

Harris, D. (2006). Music, education and Muslims. Stoke on Trent: Trentham Books.

Hubbard, L., Mehan, H., \& Stein, M. K. (2006). Reform as learning: School reform, organizational culture, and community politics in San Diego. New York: Routledge.

Izsak, K. (2013). Music education and Islam: Perspectives on Muslim participation in music education in Ontario. The Canadian Music Educator, 54(3), 38.

Knudsen, J. S. (2010). Musikkulturelt mangfold - forskjeller og fellesskap. In J. H. Sætre \& G. Salvesen (Eds.), Allmenn musikkundervisning (pp. 156-178). Oslo: Gyldendal Akademisk.

Kulturskolerådet. (2017). Strategidokument for oppfølging av Landstingsvedtak 5.1. Flyktninger og kulturskolen. http://kulturskoleradet.no/_extension/media/4683/orig/Strategidokument\%20 Fokusomrade\%20flyktninger\%20og\%20kulturskole\%205.1\%20per\%20170512.pdf

Leont'ev, A. N. (1981). Problems of the development of the mind. Moscow: Progress.

Rantavuori, J., Engeström, Y., \& Lipponen, L. (2016). Learning actions, objects and types of interaction: A methodological analysis of expansive learning among pre-service teachers. Frontline Learning Research, 4(3), 1-27. https://doi.org/10.14786/flr.v4i3.174.

Ruud, E. (2011). Musikk med helsekonsekvenser. Et musikkpedagogisk prosjekt for ungdommer i en palestinsk flyktningleir. In S. E. Holgersen \& S. G. Nielsen (Eds.), Årbok for Nordisk pedagogisk forskning (pp. 59-80). Oslo: Norwegian Academy of Music.

Ruud, E. (2012). The new health musicians. In R. Macdonald, G. Kreutz, \& L. Mitchell (Eds.), Music, health and wellbeing (pp. 87-96). Oxford: Oxford University Press.

Sæther, E. (2013). The art of stepping outside comfort zones: Intercultural collaborative learning in the international GLOMUS camp. In H. Gaunt \& H. Westerlund (Eds.), Collaborative learning in higher music education. Farnham: Ashgate Publishing Limited.

Star, S. L., \& Griesemer, J. R. (1989). Institutional ecology, 'translations' and boundary objects: Amateurs and professionals in Berkeley's Museum of Vertebrate Zoology, 1907-39. Social Studies of Science, 19(3), 387-420.

Storsve, V. R., \& Danielsen, B. Å. B. (2013). KAMP i Libanon. Prosjektprkasis i Kandidatstudiet for musikkpedagogikk (KAMP) ved NMH. In V. R. Storsve \& B. A. B. Danielsen (Eds.), Løft blikket - gjør en forskjell: erfaringer og ringvirkninger fra et musikkprosjekt $i$ Libanon (pp. 67-90). Oslo: Norges musikkhøgskole.

Storsve, V. R., Westby, I. A., \& Ruud, E. (2012). Hope and recognition. A music project among youth in a Palestinian refugee camp. In B. Å. B. Danielsen \& G. Johansen (Eds.), Educating music teachers in the new millennium (pp. 69-88). Oslo: Norwegian Academy of Music.

Vennebo, K. F. (2016). Innovative work in school development: Exploring leadership enactment. Educational Management Administration \& Leadership, 45(2), 298-315.

Vygotsky, L. S. (1978). Mind in society: The development of higher psychological processes. Cambridge: Harvard University Press. 
Waitoller, F. R., \& Kozleski, E. B. (2013). Understanding and dismantling barriers for partnerships for inclusive education: A cultural historical activity theory perspective. International Journal of Whole Schooling, 9(1), 23-42.

Wenger, E. (1998). Communities of practice: Learning, meaning, and identity. Cambridge, MA: Cambridge University Press.

Westerlund, H., Partti, H., \& Karlsen, S. (2015). Teaching as improvisational experience: Student music teachers' reflections on learning during an intercultural project. Research Studies in Music Education, 37(1), 55-75.

Open Access This chapter is licensed under the terms of the Creative Commons Attribution 4.0 International License (http://creativecommons.org/licenses/by/4.0/), which permits use, sharing, adaptation, distribution and reproduction in any medium or format, as long as you give appropriate credit to the original author(s) and the source, provide a link to the Creative Commons licence and indicate if changes were made.

The images or other third party material in this chapter are included in the chapter's Creative Commons licence, unless indicated otherwise in a credit line to the material. If material is not included in the chapter's Creative Commons licence and your intended use is not permitted by statutory regulation or exceeds the permitted use, you will need to obtain permission directly from the copyright holder.

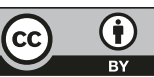

